\title{
Thrombosis Associated with Viral Hepatitis
}

\author{
Luca Galli ${ }^{1,2}$, Victor E.A. Gerdes ${ }^{2}$, Luigina Guasti ${ }^{1}$ and Alessandro Squizzato*1 \\ ${ }^{1}$ Research Center on Thromboembolic Disorders and Antithrombotic Therapies, Department of Clinical and Experimental \\ Medicine, University of Insubria, Varese, Italy; ${ }^{2}$ Department of Medicine, Slotervaart Hospital, Amsterdam, The Netherlands
}

\begin{abstract}
Viral hepatitis may promote the development of venous thromboembolism (VTE) and, more specifically, portal vein thrombosis (PVT). In this narrative review, we summarize the clinical data and discuss the possible pathogenetic roles of cytomegalovirus (CMV), Epstein-Barr virus (EBV), and hepatitis $A, B$, and $C$ viruses (HAV, HBV, HCV) in the occurrence of VTE. CMV is the first qualified candidate to enter the list of VTE minor risk factors, and in the rare case of fulminant infection, both EBV and CMV, like any severe infection or inflammatory disease, increase risk for thrombosis. In chronic hepatitis B and C, it remains controversial whether antiphospholipid antibodies are important for thrombotic complications or merely an epiphenomenon. Retinal vein occlusion described in chronic hepatitis $\mathrm{C}$ is usually attributed to the treatment with interferon. Eltrombopag, used for HCVrelated thrombocytopenia, has been associated with increased thrombotic risk. The imbalance between procoagulant and anticoagulant factors associated with chronic liver disease may have clinical implications. This may help to explain why these patients are not protected from clinical events such as VTE, PVT, and the progression of liver fibrosis. (C) 2014 The Second Affiliated Hospital of Chongqing Medical University. Published by XIA \& HE Publishing Ltd. All rights reserved.
\end{abstract}

\section{Introduction}

Viral hepatitis is a major health problem worldwide, and infected patients are at high risk of morbidity and mortality. Although acute arterial and venous thrombosis are not classically described as possible complications of viral hepatitis $^{1,2}$ both cardiovascular complications are multicausal diseases. Acute infections have been linked to a transient increased risk for both myocardial infarction and venous thromboembolism (VTE). ${ }^{3}$

Multiple factors can lead to hemostatic abnormalities, and it is well known that inflammation, and in particular some

Keywords: Hepatitis; Thrombosis; Cytomegalovirus; Epstein-Barr virus; Hepatitis A, B and C virus.

Abbreviations: $\mathrm{APC}$, activated protein $\mathrm{C}$; $\mathrm{aPL}$, antiphospholipid antibodies; CMV, cytomegalovirus; EBV, epstein-barr virus; HAV, hepatitis A virus; HBV, hepatitis B virus; HCV, hepatitis C virus; PARs, protease activated receptors; PVT, portal vein thrombosis; RVO, retinal vein occlusion; TF, tissue factor; VTE, venous thromboembolism.

Received: 3 October 2014; Revised: 19 November 2014; Accepted: 20 November 2014

DOI: $10.14218 /$ JCTH.2014.00031.

*Correspondence to: Alessandro Squizzato, U.O. Medicina I, Ospedale di Circolo, Viale Borri 57, Varese 21100, Italy. Tel: +39-0332-278831, Fax: +390332-278118, E-mail: alexsquizzo@libero.it; alessandro.squizzato@uninsubria.it viral infections, can play a key role. These alterations can range from relatively insignificant laboratory changes to severe disseminated intravascular coagulation. ${ }^{4}$ Coagulation can be activated at either the systemic or local level via two main processes: systemic inflammation and direct infection of endothelial cells. Viruses can down-regulate physiological anticoagulant mechanisms and inhibit fibrinolysis and tissue factor (TF)-mediated thrombin generation. ${ }^{4,5}$

Hepatitis viruses may increase thrombosis risk by several mechanisms. Acute viral hepatitis can induce inflammatory changes in surrounding tissues, in particular the endothelium of the portal vein system, leading to activation of the coagulation system by inflammation and increasing the risk of portal vein thrombosis (PVT). Furthermore, antiphospholipid antibodies (aPL) may be involved in thrombosis pathogenesis. ${ }^{6}$ These antibodies, as well as other autoimmune phenomena, have been associated with chronic hepatitis $C$ infection. Lastly, particular attention must be paid to chronic liver disease. Although it is classically seen as a coagulopathy leading to bleeding, there is recent evidence suggesting that in patients with chronic liver disease the risk for thrombosis may even outweigh that due to bleeding. ${ }^{7}$

On the atherothrombotic side, likewise, viral infections may contribute to atherosclerosis either through direct infection of endothelial cells or indirectly via cytokines or acute phase proteins induced by systemic inflammation. A recent review of the literature suggests a relationship between different infective pathogens and atherothrombosis: rather than the effects of a single microorganism, the aggregate burden of chronic infections might contribute to atherosclerosis and its thrombotic complications. $^{8}$ However, the real role of infection in atherosclerosis remains under debate.

In this review, we summarize current evidence on the relationship between viral hepatitis and thrombosis.

\section{Methods}

We identified and reviewed published clinical studies examining the link between viral hepatitis and thrombosis. This is an update of our previous review published in $2012 .{ }^{9}$ Overall, we searched the literature from 1966 to the second week of September 2014 using the MEDLINE electronic database. The following search terms (text words and medical subject headings (MeSH) terms) were used for the search: "viral hepatitis", "hepatitis A", "hepatitis B", "hepatitis C", "cytomegalovirus", "Epstein-Barr virus" and "thrombosis". The search was performed without any language restriction or exclusion criteria based on study design. Case series and case reports were included, and systematic reviews were considered the highest level of available evidence. When epidemiological studies were lacking, case reports are discussed. 


\section{Cytomegalovirus}

Cytomegalovirus (CMV) is a herpesvirus that may usually be asymptomatic or cause few symptoms with no long-term health consequences. CMV infection is common worldwide, and humans can acquire it even prior to birth. After the initial infection, CMV often becomes latent without detectable damage or clinical illness, but immunosuppression by medications or disease may allow the virus to reactivate and become symptomatic. Active CMV infection manifests as flulike symptoms or by a mononucleosis-like syndrome, with prolonged fever, cervical lymphadenitis, and arthralgia. ${ }^{10}$ Occasionally, it may present with more severe symptoms, such as pneumonia, hepatitis, myocarditis, pericarditis, colitis, or hemolytic anemia. ${ }^{10}$

In recent years, CMV infection has been linked to the development of venous thrombosis. ${ }^{5,9,11} \mathrm{CMV}$ seems to directly interfere with the hemostatic system. ${ }^{5}$ The activation of CMVinfected endothelial cells induces membrane perturbation and expression of adhesion molecules that, consequently, enhance platelet and leukocyte adhesion. The subsequent local inflammatory response $\mathrm{e}^{12,13}$ and tissue-factor exposure to the bloodstream may promote thrombin generation. ${ }^{5,14}$ Furthermore, the envelope of CMV has intrinsic procoagulant properties, probably acquired after infection of endothelial cells, ${ }^{5}$ which may promote thrombin generation via factor $X$ activation, surface tissue-factor activity, and procoagulant phospholipid expression. ${ }^{15-17}$ During CMV infection, increases in von Willebrand factor and factor VIII levels have been observed, and this may also promote thrombosis. ${ }^{18,19}$ In addition, CMV has been proposed to transiently increase aPL. ${ }^{20,21}$

Clinical characteristics of patients with CMV-associated venous thrombosis were summarized by Justo and colleagues. ${ }^{21}$ This meta-analysis, including 64 immunocompetent patients and 33 immunocompromised patients with mean age $39.7 \pm 14.9$ years, showed that lower limb venous thrombosis and PE were the most frequently affected sites (53.6\%) in CMV-associated thrombosis. This was followed by splanchnic thrombosis $(25.8 \%)$, with a relatively high frequency for thrombosis in unusual sites. This meta-analysis, however, did not specifically look at CMV hepatitis, but the unusually high relative risk for developing splanchnic vein thrombosis during CMV-infection suggested that viral hepatitis might play a key pathogenic role in this type of thrombosis. The inflammatory changes in the surrounding tissues, and in particular in the endothelium of the portal vein system, that could be associated with viral acute hepatitis, can activate the coagulation system and lead to splanchnic vein thrombosis. ${ }^{22}$

Recently, Para and colleagues published a community prospective study on thrombosis following acute CMV infection. ${ }^{23}$ The 6-month incidence of VTE and/or arterial thrombosis was higher in patients with acute CMV infection (tested positive for CMV-IgM antibodies) relative to CMVIgMseronegative patients. The observed VTE incidence among CMV-IgM seropositive and seronegative patients was $0.306 \%$ and $0.136 \%$, respectively (odds ratio (OR) 2.25; $95 \%$ confidence intervals (95\% CI) $1.38-3.66 ; p=0.003$ ), showing an independent association between VTE and CMVIgMseropositivity after adjustment for age, sex, and other confounders. ${ }^{23}$ Although several cases of CMV-associated arterial thrombosis (or embolism) have been previously reported, ${ }^{21,24-25}$ no association between arterial thrombosis and CMV-IgMseropositivity was demonstrated in this large community based cohort. ${ }^{23}$

\section{Epstein-barr virus}

Epstein-Barr virus (EBV), also known as human herpesvirus 4 , is, like CMV, a member of the herpes virus family. It is one of the most common human viruses, with seroprevalence rates of 90 to $95 \%$ in adults. ${ }^{9}$ EBV infection can cause the mononucleosis infectious syndrome, consisting of hepatosplenomegaly, pharyngitis, cervical lymphadenopathy, hepatitis, atypical lymphocytosis, and monocytosis, but it is usually asymptomatic or associated with flu-like symptoms only. ${ }^{9}$

In contrast to CMV, the association between VTE and EBV has rarely been described. Justo and colleagues identified only two reports of immunocompetent patients who developed EBV-associated VTE in addition to their described cases. $^{26}$ The mechanisms by which EBV infection might promote thrombosis are not fully understood. ${ }^{26}$ Plausible mechanisms include transient elevation of aPL antibodies ${ }^{27}$ and EBV-induced oxidative endothelial cell injury. ${ }^{28}$ Overall, there is insufficient information available showing any clinically relevant association between EBV and thrombosis.

\section{Hepatitis A virus, hepatitis B virus, and hepatitis C virus}

\section{Hepatitis A virus}

Hepatitis A virus (HAV) causes an acute infectious disease of the liver that is asymptomatic in the majority of children (70\%), but usually in adults produces a self-limited disease with nausea, anorexia, fever, malaise, or abdominal pain and jaundice, which does not result in chronic infection orchronic liver disease. ${ }^{9}$

To our knowledge, the report of a young woman with a cerebral venous thrombosis is the only case of VTE related to HAV to have been described in the literature. ${ }^{29}$

\section{Hepatitis B virus, hepatitis C virus and PVT}

Hepatitis B virus (HBV) can cause both acute and chronic hepatitis. In the United States alone, there were approximately 38,000 new infections in 2010, with 1.2 million people affected by chronic HBV infection. The acute illness causes liver inflammation, vomiting, jaundice, and rarely, death. Chronic HBV infection, which occurs in $5 \%$ of infected adults and older juveniles, may eventually lead to cirrhosis. ${ }^{9}$ Hepatitis $C$ is an infectious disease that primarily affects the liver and is caused by the hepatitis $\mathrm{C}$ virus (HCV). ${ }^{9}$ There are approximately 180 million people infected worldwide. ${ }^{30}$ Most people with acute infection are asymptomatic, with only 20$30 \%$ of newly infected persons developing symptoms. About $75-85 \%$ of newly infected persons will develop a chronic infection, which can be asymptomatic or lead to fibrosis of the liver and ultimately, after many years, to cirrhosis. In some cases, both HBV and HCV-related cirrhosis will progress to liver failure or other complications of cirrhosis, including liver cancer or life-threatening esophageal varices and gastric varices. $^{9}$

It is well known that PVT is a possible complication of hepatic cirrhosis and liver transplantation. Major risk factors for PVT are portal hypertension and consequent venous stasis. However, recently, the focus has shifted on the possible role of the prothrombotic state related to chronic liver disease. ${ }^{7,31-33}$ Indeed, despite chronic liver disease being classically seen as a 
Galli L. et al: Viral hepatitis and thrombosis

Table 1. Haemostasis imbalance in chronic liver disease

\begin{tabular}{lllll}
\hline & $\begin{array}{l}\text { Coagulation } \\
\text { factors }\end{array}$ & $\begin{array}{l}\text { Anticoagulant } \\
\text { factors }\end{array}$ & Platelet & Fibrinolysis \\
\hline Pro-thrombotic & $\begin{array}{l}\text { High von Willebrand } \\
\text { factor and factor VIII }\end{array}$ & $\begin{array}{l}\text { Low antithrombin } \\
\text { and protein C }\end{array}$ & & $\begin{array}{l}\text { Low plasminogen, } \\
\text { high PAI }\end{array}$ \\
Pro-haemorrhagic & $\begin{array}{l}\text { Low fibrinogen, factors II, } \\
\text { V, VII, IX, X, XI }\end{array}$ & & $\begin{array}{l}\text { Low platelet } \\
\text { count }\end{array}$ & $\begin{array}{l}\text { High tPA, low TAFI, } \\
\text { low plasmin inhibitor }\end{array}$ \\
\hline
\end{tabular}

Summarized from refs. 7, 37-39.

PAI, plasminogen activator inhibitor; tPA, tissue plasminogen activator; TAFI, thrombin-activatable fibrinolysis inhibitor; aPL, antiphospholipid antibodies.

coagulopathy leading to bleeding, it is now appreciated that there exists a delicate hemostatic balance (see Table 1) between reduced production of procoagulant factors and platelets and decreased levels of anticoagulants (such as protein C and antithrombin) in cirrhosis. ${ }^{7}$ Tripodi et al. ${ }^{38}$ demonstrated in vitro that the activated protein C (APC) resistance test was impaired in cirrhotic patients and worsened with progressive deterioration of liver disease from Child Pugh Class A to $\mathrm{C}$. This resulted in a hypercoagulable state similar to that conferred by congenital protein $\mathrm{C}$ deficiency or Factor $\mathrm{V}$ Leiden mutation. ${ }^{38,39} \mathrm{~A}$ recent in vitro study showed that the procoagulant imbalance decreased when exogenous purified protein $C$ was added to restore levels to normal. ${ }^{40}$ Furthermore, chronic liver disease was associated with normal, or even increased, thrombin generation. ${ }^{7}$

It is uncertain whether HBV and HCV themselves cause PVT. There is some evidence suggesting that chronic viral infection is a thrombotic risk factor, perhaps by infection-mediated inflammation and hemostatic impairment. $\mathrm{aPL}^{32,33}$ and prothrombotic state associated with chronic liver disease ${ }^{7}$ seems to play an important role in virus-associated thrombosis. aPL are classically described in association with viral infections ${ }^{32}$ and can affect up to $33 \%$ of patients with hepatitis C, ${ }^{34}$ but the real etiology and thrombogenic potential of these autoantibodies in this setting are still largely unknown. ${ }^{35}$ Even though aPL may be just an epiphenomenon of chronic viral hepatitis, several authors have suggested that they may be responsible for thrombotic events occurring in patients with chronic hepatitis. ${ }^{36,37}$

\section{$H B V, H C V$, and arterial and venous thrombosis}

The risk of developing other arterial and venous thromboembolic events in patients with chronic liver disease is not well defined. Only recently it was suggested that the incidence of thrombotic events other than PVT is increased in these patients. Enger and colleagues calculated the incidence of venous and arterial thromboembolic events among patients with hepatitis $C$ virus (HCV) infection $(n=22,733)$ and matched comparators $(n=69,198)$ as well as patients with cirrhosis $(n=15,158)$ and matched comparators $(n=45,473) .^{31}$ The incidence for any thromboembolic event was 233.4 events per 10,000 person-years for the HCV cohort and 138.5 per 10,000 person-years for the comparators, with an adjusted incidence rate ratio for any thromboembolic event of 1.62 (95\% CI: 1.48-1.77). The incidence of any thromboembolic event was 561.1 per 10,000 person-years for the cirrhosis patients and 249.7 per 10,000 person-years for the comparators, with an adjusted incidence rate ratio of 2.28 (95\% CI: $2.11-2.47) .^{31}$

\section{Drug-related thrombosis}

The conventional treatment for hepatitis $C$ infection is a combination of pegylated interferon- $\alpha-2$ a or pegylated interferon $-\alpha-2 b$ and the antiviral drug ribavirin for a period of 24 or 48 weeks, depending on the HCV genotype. ${ }^{9}$ Chronic liver disease associated with HCV infection can often be complicated by thrombocytopenia, and its severity is usually correlated with liver disease severity and the presence of portal hypertension. ${ }^{41-43}$ Pegylated interferon and ribavirin can induce bone marrow suppression, thereby causing further reduction of platelet counts ${ }^{44}$ and leading to treatment discontinuation or dose reduction.

Eltrombopag, an oral thrombopoietin receptor agonist, was recently approved in the United States for treatment of thrombocytopenia in patients with chronic hepatitis $\mathrm{C}$ in order to allow for the initiation and maintenance of interferon-based therapy. Eltrombopag was shown to increase platelet numbers in thrombocytopenic patients with HCV and advanced fibrosis and cirrhosis. This allowed ineligible or marginal patients to begin and maintain antiviral therapy. ${ }^{45}$ However, there is concern growing about the safety of these drugs in patients with cirrhosis associated coagulation alterations. As mentioned earlier, these patients have lower concentrations of coagulation factors and inhibitory factors, leading to a less balanced coagulation system. Indeed, eltrombopag has been found to cause thromboembolism, especially PVT at normal or even subnormal platelet levels. ${ }^{46-52}$ Data from ENABLE-1 and ENABLE- 2 study ${ }^{45}$ showed that during the antiviral phase, there were 34 thromboembolic events in 31 eltrombopag patients ( $3 \%$ ) and only five in placebo patients (1\%). PVT was the most common event in both treatment groups $(n=12,1 \%$ eltrombopag; $n=2,<1 \%$ placebo). ${ }^{45}$ Thus, eltrombopag should only be used after a careful assessment of the benefit and risk profile, particularly in those patients with clear evidence of hepatic impairment.

It is unclear how eltrombopag promotes thromboembolism despite normal or subnormal platelet counts. It is unlikely that eltrombopag therapy itself produces any ill effects on platelet function, as platelets in HCV-related thrombocytopenia, such as in patients with primary chronic immune thrombocytopenia, are thought to become more 'sticky' and more prone to aggregate and form a thrombus. ${ }^{49,50}$ There are, however, no clear data in the literature demonstrating whether eltrombopag increases the physiological tendency of platelets to adhere or aggregate, and more studies are needed to resolve this controversy. Finally, rapid increase in platelet count induced by eltrombopag and chronic liver disease-associated endothelial dysfunction may contribute to the increased thrombotic risk. 
Galli L. et al: Viral hepatitis and thrombosis

Table 2. Viral hepatitis and thrombosis - possible underlying mechanisms

\begin{tabular}{ll}
\hline Virus & Prothro mbotic mechanism \\
\hline CMV & $\begin{array}{l}\text { Endothelial dysfunction with increased TF exposure and increased } \\
\text { leukocyte adhesion; increased TF exposure in CMV-infected } \\
\text { monocytes; procoagulant properties of CMV envelope; aPL } \\
\text { aPL, oxidative endothelial cell injury }\end{array}$ \\
HAV, HBV, HCV & Cirrhosis-related prothrombotic state; aPL; drugs \\
\hline
\end{tabular}

CMV, cytomegalovirus; TF, tissue factor; aPL, antiphospholipid antibodies; VTE, venous thromboembolism; EBV, Epstein-Barr virus; HAV, HBC, HCV, hepatitis A, B, C virus.

In addition to interferon- $\alpha$-related retinopathy, some cases of retinal vein occlusion (RVO) have been described in chronic hepatitis $C$ patients on interferon and ribavirin combination therapy. ${ }^{53-58}$ Since there are few cases available regarding RVO in patients on interferon and ribavirin, it is uncertain whether the treatment or the underlying condition cause the complication. ${ }^{53}$ The precise mechanisms underlying the development of RVO in these patients are not established yet, but it is possible that interferon favours the formation of aPL and the induction of plasma-activated complement $\mathrm{C} 5 \mathrm{a}$, a potent intravascular aggregator of granulocytes. ${ }^{59-60}$

Ischemic colitis is another rare complication of interferon treatment. To date, 12 cases have been described in eight papers. ${ }^{61-68}$ The pathophysiology of interferon-related ischemic colitis is not clear. Possible mechanisms of action are the following: gastrointestinal vasculitis secondary to the immune-modulating effects of interferon, a direct vasospastic effect by interferon leading to a decrease in blood flow to the colon, ${ }^{67}$ or hypotension, a known rare adverse effect of interferon treatment. ${ }^{69}$

\section{Liver fibrosis and the coagulation system}

The development of hepatic fibrosis in patients with chronic liver injury represents a complex disease trait that is modulated by the interaction of host genetic factors and environmental influences, in which the coagulation system may play a relevant role. ${ }^{70}$ Thrombin not only has procoagulant function, but it also binds to several receptors called protease activated receptors (PARs). The presence of these thrombin receptors has been associated with increased severity of liver disease. ${ }^{71}$ Moreover, coagulation cascade activity mediated by activatedfactor $X$ may favor hepatic fibrosis. ${ }^{72,73}$

A recent retrospective multicenter study evaluated the role of daily low-dose aspirin (75 or $100 \mathrm{mg}$ ) in fibrosis progression in liver transplant recipients with recurrent HCV infection. ${ }^{74}$ In total, $188 \mathrm{HCV}$-positive patients who had undergone liver transplantation between 2000 and 2010 were included. Liver fibrosis was assessed by histological evaluation. Progression to fibrosis $F \geq 2$ was analyzed with a multistate model with time-dependent variables. In the multivariate analysis, younger recipient age and aspirin intake (hazard ratio 0.65 , CI 0.47-0.91) were associated with slower fibrosis progression. ${ }^{74}$ To the best of our knowledge, there are no intervention studies available regarding the effect of platelet aggregation inhibitors, such as aspirin, or anticoagulant therapy on fibrosis progression.

\section{Conclusions}

There is mounting evidence suggesting that viral hepatitis may increase thrombotic risk (see Table 2 and Table 3). CMV is the first qualified candidate to enter the list of VTE minor risk factors: both clinical and laboratory data suggest a causative role. Although CMV is certainly not a major risk factor, the multicausal nature of VTE may predispose patients with CMV hepatitis to cross the thrombosis threshold in the presence of other risk factors. ${ }^{1}$ The link between HBV/HCV and VTE and

Table 3. Viral hepatitis and thrombosis - clinical evidence

\begin{tabular}{lll}
\hline Virus & Best available level of evidence & Findings \\
\hline CMV & Systematic review ${ }^{21}$ & $\begin{array}{l}\text { CMV is not a VTE major risk factor, but it is a good VTE minor risk factor candidate. } \\
\text { Splanchnic vein thrombosis was the second most prevalent thrombosis associated } \\
\text { with acute CMV infection, after lower limbs DVT and PE. }\end{array}$ \\
EBV Case report ${ }^{26}$ & $\begin{array}{l}\text { Association with VTE was rarely described, mostly in immunocompromised patients. } \\
\text { Mechanisms by which EBV infection might trigger thrombosis not fully understood. }\end{array}$ \\
HAV Case report ${ }^{29}$ & $\begin{array}{l}\text { Only one case reported of a cerebral venous thrombosis assumed as related to HAV } \\
\text { hepatitis }\end{array}$ \\
HBV Cross-sectional study ${ }^{77-78}$ & $\begin{array}{l}\text { It is uncertain whether HBV itself cause VTE or PVT, but chronic viral infection may be } \\
\text { and adional thrombotic risk factor. } \\
\text { Some studies suggest that HBV is the major risk factor for PVT in Southeast Asian } \\
\text { populations, where PVT mainly occurs in patients with post-hepatitis B liver cirrhosis. } \\
\text { Patients with HCV and cirrhosis are at increased risk of thromboembolic events, even } \\
\text { though it is uncertain whether HCV itself cause VTE or PVT. } \\
\text { The increasing numbers of treatment available for chronic hepatitis C may shift the } \\
\text { hemostatic balance from hemorrhagic to thrombotic complications }\end{array}$ \\
\hline
\end{tabular}

CMV, cytomegalovirus; EBV, Epstein-Barr virus; HAV, HBC, HCV, hepatitis A, B, C virus; VTE, venous thromboembolism; DVT, deep vein thrombosis; PE, pulmonary embolism; PVT, portal vein thrombosis. 
PVT is more ambiguous. There are some indications, however, that there is a connection. ${ }^{31,75-76}$ The increasing number of treatments available for chronic hepatitis $\mathrm{C}$ may shift the haemostatic balance from hemorrhagic to thrombotic complications. ${ }^{77}$ The procoagulant state associated with chronic liver disease has a direct clinical consequence: the unrestricted use of plasma infusion to correct the results of conventional coagulation tests in patients undergoing invasive procedures may be useless, or even harmful. ${ }^{7}$ Indeed, the guidelines of the American Association for the Study of Liver Diseases warns against the indiscriminate use of plasma therapy before liver biopsy. ${ }^{78}$ Finally, the activation of the coagulation system may be directly detrimental on the progression of liver disease, with mounting evidence suggesting that liver fibrosis deposition is also mediated by coagulation factor activation.

Several issues remain unresolved. First, would be a benefit to cirrhotic inpatients of routine thromboprophylaxis; second, would patients with an apparently "unprovoked" VTE and a concomitant CMV or EBV infection be redefined as a "provoked" VTE event; and, finally, which, if any, antithrombotic drugs would be beneficial in limiting liver fibrosis.

\section{Conflict of interest}

None

\section{Author contributions}

Drafting of manuscript (LG, AS), critical revision (VEAG, LG).

\section{References}

[1] Rosendaal FR. Venous thrombosis: a multicausal disease. Lancet 1999;353: 1167-1173 doi: 10.1016/S0140-6736(98)10266-0.

[2] Denninger MH, Chaït Y, Casadevall N, Hillaire S, Guillin MC, Bezeaud A, et al. Cause of portal or hepatic venous thrombosis in adults: the role of multiple concurrent factors. Hepatology 2000;31:587-591. doi: 10.1002/ hep. 510310307

[3] Smeeth L, Cook C, Thomas S, Hall A], Hubbard R, Vallance P. Risk of deep vein thrombosis and pulmonary embolism after acute infection in a community setting. Lancet 2006;367:1075-1079. doi: 10.1016/S0140-6736(06) 68474-2.

[4] Levi M, Keller TT, van Gorp E, ten Cate H. Infection and inflammation and the coagulation system. Cardiovasc Res 2003;60:26-39. doi: 10.1016/S00086363(02)00857-X

[5] Squizzato A, Gerdes VEA, Büller HR. Effects of human cytomegalovirus infection on the coagulation system. Thromb Haemost 2005;93:403-410. doi: http://dx.doi.org/10.1160/TH04-08-0523.

[6] Zignego AL, Ferri C, Pileri SA, Caini P, Bianchi FB, Italian Association of the Study of Liver Commission on Extrahepatic Manifestations of HCV infection. Extrahepatic manifestations of Hepatitis C Virus infection: a general overview and guidelines for a clinical approach. Dig Liver Dis 2007;39:2-17. doi: 10.1016/j.dld.2006.06.008.

[7] Tripodi A, Mannucci PM. The coagulopathy of chronic liver disease. N Engl ] Med 2011;365:147-156. doi: 10.1056/NEJMra1011170.

[8] Tufano A, Di Capua M, Coppola A, Conca P, Cimino E, Cerbone AM, et al. The infectious burden in atherothrombosis. Semin Thromb Hemost 2012;38:515523.

[9] SquizzatoA, GerdesVEA. Viral hepatitis and thrombosis: a narrative review. Semin Thromb Hemost 2012;38:530-534.

[10] http://www.cdc.gov, accessed September 2014.

[11] Tichelaar VY, Sprenger HG, Makelburg AB, Niesters BG, Kluin-Nelemans HC, Lijfering WM. Active cytomegalovirus infection in patients with acute venous thrombosis: a case-control study. Am J Hematol 2011;86:510-512. doi: 10.1002/ajh.22006.

[12] Rahbar A, Soderberg-Naucler C. Human cytomegalovirus infection of endothelial cells triggers platelet adhesion and aggregation. J Virol 2005; 79:2211-2220. doi: 10.1128/JVI.79.4.2211-2220.2005.

[13] Span AH, van Dam-Mieras MC, Mullers W, Endert J, Muller AD, Bruggeman CA. The effect of virus infection on the adherence of leukocytes or platelets to endothelial cells. Eur ] Clin Invest 1991;21:331-338. doi: 10.1111/j.13652362.1991.tb01378.x

[14] Van Dam-Mieras MC, Muller AD, van Hinsbergh VW, Mullers WJ, Bomans PH Bruggeman CA. The procoagulant response of cytomegalovirus infected endothelial cells. Thromb Haemost 1992;68:364-370.

[15] Van Dam-Mieras MC, Bruggeman CA, Muller AD, Debie WH, Zwaal RF. Induction of endothelial cell procoagulant activity by cytomegalovirus infection. Thromb Res 1987;47:69-75. doi: 10.1016/0049-3848(87)90241-6.

[16] Sutherland MR, Raynor CM, Leenknegt H, Wright JF, Pryzdial EL. Coagulation initiated on herpesviruses. Proc Natl Acad Sci U S A 1997;94:13510-13514. doi: $10.1073 /$ pnas.94.25.13510

[17] Pryzdial EL, Wright JF. Prothrombinase assembly on an enveloped virus: evidence that the cytomegalovirus surface contains procoagulant phospholipid. Blood 1994;84:3749-3757.

[18] Schambeck CM, Hinney K, Gleixner J, Keller F. Venous thromboembolism and associated high plasma factor VIII levels: linked to cytomegalovirus infection? Thromb Haemost 2000;83:510-511.

[19] The TH, Kas-Deelen AM, de Maar EF, Driessen C, Harmsen MC, van Son W]. Cellular and humoral parameters for vascular damage in blood during cytomegalovirus infections. Transplant Proc 2001;33:1813. doi: 10.1016/ S0041-1345(00)02692-0.

[20] Delbos V, Abqueguen $P$, Chennebault JM, Fanello S, Pichard E. Acute cytomegalovirus infection and venous thrombosis: role of antiphospholipid antibodies. J Infect 2007;54:e47-e50. doi: http://dx.doi.org/10.1016/ j.jinf.2006.03.031.

[21] Justo D, Finn T, Atzmony L, Guy N, Steinvil A. Thrombosis associated with acute cytomegalovirus infection: a meta-analysis. Eur J Intern Med 2011;22: 195-199. doi: 10.1016/j.ejim.2010.11.006

[22] Squizzato A, Ageno W, Cattaneo A, Brumana N. A case report and literature review of portal vein thrombosis associated with cytomegalovirus infection in immunocompetent patients. Clin Infect Dis 2007;44:e13-e16. doi: 10.1086/ 509641.

[23] Paran $Y$, Shalev $V$, Steinvil $A$, Justo $D$, Zimmerman $O$, Finn $T$, et al. Thrombosis following acute cytomegalovirus infection: a community prospective study. Ann Hematol 2013;92:969-974. doi: 10.1007/s00277-0131715-3.

[24] Madalosso C, de Souza NF, Jr IDM, Wiesner RH, Krom RA. Cytomegalovirus and its association with hepatic artery thrombosis after liver transplantation. Transplantation 1998;66:294-297. doi: 10.1097/00007890-19980815000003.

[25] Protopapa MN, Velissaris D, Mougiou A, Siagkris D. Cytomegalovirusassociated splenic infarcts in an adult immune-competent man: a case report and review of the literature. J Med Case Rep 2014;8:85. doi: 10.1186/1752 1947-8-85.

[26] Mashav N, Saar N, Chundadze T, Steinvil A, Justo D. Epstein-Barr virusassociated venous thromboembolism: a case report and review of the literature. Thromb Res 2008;122:570-571. doi: 10.1016/j.thromres.2008.03.005.

[27] Yamazaki M, Asakura H, Kawamura Y, Ohka T, Endo M, Matsuda T. Transient lupus anticoagulant induced by Epstein-Barr virus infection. Blood Coagul Fibrinolysis 1991;2:771-774. doi: 10.1097/00001721-19911200000012.

[28] Dalpke AH, Thomssen R, Ritter K. Oxidative injury to endothelial cells due to Epstein-Barr virus-induced autoantibodies against manganese superoxide dismutase. J Med Virol 2003;71:408-416. doi: 10.1002/jmv.10501.

[29] Zis P, Kontogeorgi E, Karakalos D, Pavlopoulou D, Sevastianos VA. Cerebra venous thrombosis as an extrahepatic manifestation of acute anicteric hepatitis A infection. Case Rep Neurol Med. 2012;2012:120423. doi $10.1155 / 2012 / 120423$.

[30] Kamal SM. Acute hepatitis C: a systematic review. Am J Gastroenterol 2008; 103:1283-1297, quiz 1298. doi: 10.1111/j.1572-0241.2008.01825.x.

[31] Enger C, Forssen UM, Bennett D, Theodore D, Shantakumar S, McAfee A Thromboembolic events among patients with hepatitis $C$ virus infection and cirrhosis: a matched-cohort study. Adv Ther 2014;31:891-903. doi: 10.1007/s12325-014-0138-4.

[32] Shoenfeld Y. Systemic antiphospholipidsyndrome. Lupus 2003;12:497-498. doi: 10.1191/0961203303lu396xx.

[33] Mangia A, Margaglione M, Cascavilla I, Gentile R, Cappucci G, Facciorusso D, et al. Anticardiolipin antibodies in patients with liver disease. Am J Gastroenterol 1999;94:2983-2987. doi: 10.1111/j.15720241.1999.01447.x

[34] Biron C, Andreani H, Blanc P. Prevalence of antiphospholipid antibodies in patients with chronic liver disease related to alcohol or hepatitis $C$ virus: correlation with liver injury. J Lab Clin Med 1998;131:243-250. doi: 10.1016/ S0022-2143(98)90096-8.

[35] Violi F, Ferro D, Basili S, Artini M, Valesini G, Levrero M, et al. Increased rate of thrombin generation in hepatitis $C$ virus cirrhotic patients. Relationship to venous thrombosis. J Investig Med 1995;43:550-554.

[36] Prieto J, Yuste JR, Beloqui O, Civeira MP, Riezu JI, Aguirre B, et al. Anticardiolipin antibodies in chronic hepatitis $\mathrm{C}$ : implication of hepatitis $\mathrm{C}$ 
virus as the cause of the antiphospholipid syndrome. Hepatology $1996 ; 23$ : 199-204. doi: 10.1002/hep.510230201.

[37] Daniels AH, Wilson CL, Harrison RA. Hepatitis C-associated leukocytoclasticvasculitis with anticardiolipin antibodies causing penile necrosis and deep venous thrombosis in the absence of cryoglobulinemia. J Hosp Med 2008; 3: 170-172. doi: 10.1002/jhm.261.

[38] Tripodi A, Primignani M, Chantarangkul V, Dell'Era A, Clerici M, de Franchis R, et al. An imbalance of pro- vs anti-coagulation factors in plasma from patients with cirrhosis. Gastroenterology 2009;137:2105-2111. doi: 10.1053/j.gastro.2009.08.045.

[39] Tripodi A, Primignani M, Lemma L, Chantarangkul V, Dell'Era A, Iannuzzi $F_{\text {, }}$ et $a l$. Detection of the imbalance of procoagulant versus anticoagulant factors in cirrhosis by a simple laboratory method. Hepatology $2010 ; 52$ : 249-255. doi: 10.1002/hep.23653.

[40] Tripodi A, Primignani M, Lemma L, Chantarangkul V, Mannucci PM. Evidence that low protein $\mathrm{C}$ contributes to the procoagulant imbalance in cirrhosis. J Hepatol 2013;59:265-270. doi: 10.1016/j.jhep.2013.03.036.

[41] Louie KS, Micallef JM, Pimenta JM, Forssen UM. Prevalence of thrombocytopenia among patients with chronic hepatitis C: a systematic review. J Viral Hepat 2011;18:1-7. doi: 10.1111/j.1365-2893.2010.01366.x.

[42] Streiff MB, Mehta S, Thomas DL. Peripheral blood count abnormalities among patients with hepatitis C in the United States. Hepatology 2002;35:947-952. doi: 10.1053/jhep.2002.32486.

[43] Giannini EG. Review article: thrombocytopenia in chronic liver disease and pharmacologic treatment options. Aliment Pharmacol Ther 2006;23:10551065. doi: $10.1111 / j .1365-2036.2006 .02889 . x$.

[44] Schmid M, Kreil A, Jessner W, Homoncik M, Datz C, Gangl A. Suppression of haematopoiesis during therapy of chronic hepatitis $C$ with different interferon alpha mono and combination therapy regimens. Gut 2005;54:1014-1020. doi: 10.1136/gut.2004.057893.

[45] Afdhal NH, Dusheiko GM, Giannini EG, Chen PJ, Han KH, Mohsin A, et al. Eltrombopag increases platelet numbers in thrombocytopenic patients with HCV infection and cirrhosis, allowing for effective antiviral therapy. Gastroenterology 2014;146:442-452. doi: 10.1053/j.gastro.2013.10.012.

[46] Afdhal NH, Giannini EG, Tayyab G, Mohsin A, Lee JW, Andriulli A, et al. Eltrombopag before procedures in patients with cirrhosis and thrombocytopenia. ELEVATE Study Group. N Engl J Med 2012;367:716-724.

[47] Provan D, Saleh M, Goodison S, Rafi R, Stone N, Hamilton JM, et al. The safety profile of eltrombopag, a novel, oral platelet growth factor, in thrombocytopenic patients and healthy subjects. J. Clin Oncol 2006;24:18596.

[48] Erhardt J, Erickson-Miller CL, Tapley P. SB 497115-GR, a low molecular weight TPOR agonist, does not induce platelet activation or enhance agonistinduced platelet aggregation in vitro. Blood 2004;104:Abstract 3888.

[49] Severinsen MT, Engebjerg MC, Farkas DK, Jensen AØ, Nørgaard M, Zhao S, et al. Risk of venous thromboembolism in patient with primary chronic immune thrombocytopenia: a Danish population-base cohort study. $\mathrm{Br}$ J Haemato 2011;152:360-362. doi: 10.1111/j.1365-2141.2010.08418.x.

[50] Haselboeck J, Pabinger I, AY C, Koder S, Panzer S. Platelet activation and function during eltrombopag treatment in immune thrombocytopenia. Ann Hematol 2012;91:109-113. doi: 10.1007/s00277-011-1249-5.

[51] Cuker A. Toxicities of the thrombopoietic growth factors. Semin Hematol 2010;47:289-298. doi: 10.1053/j.seminhematol.2010.03.002.

[52] Lambert MP. Platelets and eltrombopag: a not-so-sticky situation. Blood 2012;119:3876-3877. doi: 10.1182/blood-2012-03-410415.

[53] Nadir A, Amin A, Chalisa N, van Thiel DH. Retinal vein thrombosis associatedwith chronic hepatitis $\mathrm{C}$ : a case series and review of the literature. J Viral Hepat 2000;7:466-470. doi: 10.1046/j.1365-2893.2000.00245.x.

[54] Ortega-Ibarra FS, Remes-Troche JM. Retinal thrombosis secondary to the combination therapy of pegylated interferon and ribavirin for chronic hepatitis C virus infection. A rare complication. Rev Esp Enferm Dig. 2013 May-Jun;105:291-292. doi: 10.4321/S1130-01082013000500007.

[55] Nicolò M, Artioli S, La Mattina GC, Ghiglione D, Calabria G. Branch retinal artery occlusion combined with branch retinal vein occlusion in a patient with hepatitis C treated with interferon and ribavirin. Eur J Ophthalmol 2005;15:811-814.

[56] Sene D, Touitou V, Bodaghi B, Saadoun D, Perlemuter G, Cassoux N, et al. Intraocular complications of IFN-alpha and ribavirin therapy in patients with chronic viral hepatitis C. World J Gastroenterol 2007;13:3137-3140. doi: 10.3748/wjg.v13.i22.3137.

[57] Murata M, Tamura Y, Ohsawa M, Hirano T, Matsuo T, Murata T. Central retinal vein occlusion in hypertensive patients with chronic hepatitis $C$ treated with interferon alpha and ribavirin. Jpn J Ophthalmol 2008;52:511-513. doi: 10.1007/s10384-008-0585-z. Epub 2008 Dec 17.
[58] Kim ET, Kim LH, Lee JI, Chin HS. Retinopathy in hepatitis C patients due to combination therapy with pegylated interferon and ribavirin. Jpn J Ophthalmol 2009;53:598-602. doi: 10.1007/s10384-009-0738-8.

[59] Balderramo DC, García O, Colmenero J, Espinosa G, Forns X, Ginès P. Antiphospholipid syndrome during pegylated interferon alpha-2a therapy for chronic hepatitis C. Dig Liver Dis 2009;41:e4-e7. doi: 10.1016/j.dld. 2007.11.029.

[60] Sugano S, Suzuki T, Watanabe M, Ohe K, Ishii K, Okajima T. Retinal complications and plasma C5a levels during interferon alpha therapy for chronic hepatitis C. Am J Gastroenterol 1998;93:2441-2444. doi: 10.1111/ j.1572-0241.1998.00701.x.

[61] Okanoue T, Sakamoto S, Itoh Y, Minami M, Yasui K, Sakamoto M, et al. Side effects of high-dose interferon therapy for chronic hepatitis C. J Hepatol 1996;25:283-291. doi: 10.1016/S0168-8278(96)80113-9.

[62] Horigome $\mathrm{H}$, Takezono $\mathrm{Y}$, Fujino N, Uchida A, Murasaki G. [A case of ischemic colitis associated with interferon treatment]. Nihon Shokakibyo Gakkai Zasshi 1996;93:181-184.

[63] Wenner WJ, Piccoli DA. Colitis associated with alpha interferon? J Clin Gastroenterol 1997;25:398-399.

[64] Punnam SR, Pothula VR, Gourineni N, Punnam A, Ranganathan V. Interferonribavirin-associated ischemic colitis. J Clin Gastroenterol 2008;42:323-325. doi: $10.1097 / 01 . \mathrm{mcg} .0000225637 .37533 .68$.

[65] Tada H, Saitoh S, Nakagawa Y, Hirana H, Morimoto M, Shima T, et al. Ischemic colitis during interferon-alpha treatment for chronic active hepatitis C. J Gastroenterol 1996;31:582-584. doi: 10.1007/BF02355061.

[66] Leung Y, Urbanski SJ, Schindel L, Myers RP. Ischemic colitis during pegylated interferon-alpha and ribavirin therapy for chronic hepatitis C. Can J Gastroenterol 2006;20:661-663.

[67] Kawaguchi T, Ide T, Itou M, Suetsugu M, Yoshioka S, Sakata M, et al. Ischaemic colitis during interferon treatment for chronichepatitis C: report of two cases and literature review. J Viral Hepat. 2012,19:e220-e224. doi: 10.1111/ j.1365-2893.2011.01501.x.

[68] Baik SJ, Kim TH, Yoo K, Moon IH, Cho MS. Ischemic colitisduring interferonribavirin therapy for chronic hepatitis C: A case report. World J Gastroentero 2012;18:4233-4236. doi: 10.3748/wjg.v18.i31.4233.

[69] Chang L, Kahler KH, Sarawate C, Quimbo R, Kralstein J. Assessment of potential risk factors associated with ischaemic colitis. Neurogastroenterol Motil 2008;20:36-42. doi: 10.1111/j.1365-2982.2007.01015.x.

[70] Anstee QM, Dhar A, Thursz MR. The role of hypercoagulability in liver fibrogenesis. Clin Res Hepatol Gastroenterol 2011;35:526-533. doi: 10.1016/j.clinre.2011.03.011.

[71] Wright M, Goldin R, Hellier S, Knapp S, Frodsham A, Hennig B, et al. Factor V Leiden polymorphism and the rate of fibrosis development in chronic hepatitis C virus infection. Gut 2003;52:1206-1210. doi: 10.1136/ gut.52.8.1206.

[72] Levy GA, Liu M, Ding J, Yuwaraj S, Leibowitz J, Marsden PA, et al. Molecular and functional analysis of the human prothrombinase gene (HFGL2) and its role in viral hepatitis. Am J Pathol 2000;156:1217-1225. doi: 10.1016/ S0002-9440(10)64992-9.

[73] Marsden PA, Ning Q, Fung LS, Luo X, Chen Y, Mendicino M, et al. The Fgl2/ fibroleukinprothrombinase contributes to immunologically mediated thrombosis in experimental and human viral hepatitis. J Clin Invest 2003;112:5866. doi: $10.1172 / \mathrm{JCI} 18114$.

[74] Poujol-Robert A, Boëlle PY, Conti F, Durand F, Duvoux C, Wendum D, et al. Aspirin may reduce liver fibrosis progression: Evidence from a multicenter retrospective study of recurrent hepatitis $\mathrm{C}$ after liver transplantation. Clin Res Hepatol Gastroenterol 2014;38:570-576. doi: 10.1016/j.clinre.2014.07.004.

[75] Lertpipopmetha K, Auewarakul CU. High incidence of hepatitis B infectionassociated cirrhosis and hepatocellular carcinoma in the Southeast Asian patients with portal vein thrombosis. BMC Gastroenterol. 2011;11:66. doi: 10.1186/1471-230X-11-66.

[76] Chen H, Trilok G, Wang F, Qi X, Xiao J, Yang C. A single hospital study on portal vein thrombosis in cirrhotic patients - clinical characteristics \& risk factors. Indian J Med Res 2014;139:260-266. doi: 10.1111/j.15387836.2011.04429.x.

[77] Tripodi A, Anstee QM, Sogaard KK, Primignani M, Valla DC. Hypercoagulability in cirrhosis: causes and consequences. J Thromb Haemost 2011;9:17131723. doi: 10.1111/j.1538-7836.2011.04429.x.

[78] Rockey DC, Caldwell SH, Goodman ZD, Nelson RC, Smith AD, American Association for the Study of Liver Diseases. Liver biopsy. Hepatology 2009 ; 49:1017-1044. doi: 10.1002/hep.22742. 